\title{
Evaluation of Prezygotic Barrier Using Laboratory Crosses Between Three Species of Blue Mussels of The Genus Mytilus, Present Along the Chilean Coast
}

\author{
Jorge E Toro*1, Xiomara B Avila ${ }^{1}$, Pablo A Oyarzún ${ }^{2}$ and Alex Illesca ${ }^{1}$ \\ ${ }^{1}$ Instituto de Ciencias Marinas y Limnógicas, Universidad Austral de Chile, Chile \\ ${ }^{2}$ Centro de Investigación Marina Quintay (CIMARQ), Universidad Andres Bello, Quintay, Chile
}

*Corresponding author: Jorge E Toro, 1Instituto de Ciencias Marinas y Limnógicas, Universidad Austral de Chile, Chile

\section{ARTICLE INFO}

Received: 幽 February 16, 2021

Published: 幽 February 23, 2021

Citation: Jorge E Toro, Xiomara B Avila, Pablo A Oyarzún, Alex Illesca. Evaluation of Prezygotic Barrier Using Laboratory Crosses Between Three Species of Blue Mussels of The Genus Mytilus, Present Along the Chilean Coast. Biomed J Sci \& Tech Res 34(1)-2021. BJSTR. MS.ID.005505.

Keywords: Hybrids; Mytilus; Blue Mussels; Chile

\section{ABSTRACT}

The genus Mytilus, is composed by 5 species; M. californianus (Conrad 1837), $M$. edulis (Linnaeus 1758), M. galloprovincialis (Lamarck 1819), M. trossulus (Gould, 1850) and recently the Mytilus chilensis (Hupé, 1854) species have been confirmed as a true species. In the Chilean coast until 2005 the only Mytilus species present was M. chilensis, however, during the last 15 years two new exotic mussel species have been described (M. edulis and M. galloprovincialis). The scientific literature has described evidence that natural hybridization between the Mytilus species have been occurring in several hybrid zones around the world. If this phenomenon occurs in Chile, could cause a tremendous impact on the biodiversity of marine life and also on the aquaculture industry based on M. chilensis in Chile. The aim of the present study was to determine, under laboratory conditions; the percentage of fecundation using a factorial crosses design with the three species of Mytilus present in Chile.

The results obtained, showed that even do significant differences exist among the percentage of fecundation among crosses, there were no significant differences between pure species crosses and the hybrid crosses. Therefore, no prezygotic barrier was found in any of the interspecies crosses. More studies are needed to establish the fitness of larvae and juveniles obtained by each of these crosses, because, even if there is no reproductive barrier between species the viability and survivorship of the juveniles can be affected if these mussels are expose to different environmental conditions.

\section{Introduction}

Marine mussels represent an important component of the intertidal and subtidal communities and estuaries, in terms of the number of individuals and of biomass and production and are also of considerable economic importance to aquaculture in many regions of the world [1,2]. The genus Mytilus is composed of at least five morphologically similar but genetically distinct species, Mytilus edulis Linnaeus, 1758 (in eastern U.S.A. and Canada, northern Europe, Southern Argentina, the Falkland Islands, and Kerguelen Island), Mytilus galloprovincialis Lamarck, 1819 (in the Mediterranean, western Australia, Tasmania, New Zealand, sympatrically with M. edulis in parts of Great Britain, Ireland and France, and accidentally introduced into: Japan, Hong Kong, South Africa, southern California, Chile and Brasil), M. trossulus Gould,
1850 (in the northern Pacific from Siberia to central California, the Canadian Atlantic provinces, and the Baltic Sea), Mytilus chilensis (Southern Chile) and Mytilus californianus (Pacific coast of USA).

The M. chilensis aquaculture began in 1943 in Chiloé Island, southern Chile, and the aquaculture production increased rapidly from 3,864 t in 1993 to $398,274 \mathrm{t}$ in 2019 [3]. The issue with regard to the recently published evidence of the presence and potential dissemination of alien mussel species in the Chilean coast could cause a tremendous damage to the Chilean indigenous mussel (M. chilensis) aquaculture growing industry. In Chile the scientific literature described the presence of the blue mussel $M$. galloprovincialis in Tongoy Bay [4], central [5] and in southern coast of Chile [6]. The presence of M. edulis has been described in 
the inner coast of the Chiloé Island [7] and in the Straits of Magellan. Unfortunately, among some of the main features of these Mytilus species is the well-known capability to naturally hybridize among them in locations where their distributions overlap [8,9], therefore, these alien mussel species could have also the potential for natural hybridization with the native mussel M. chilensis.

In fact, there is clear evidence for a high fitness of hybrids mussels resulting in the $\mathrm{F} 1$ from the interbreeding between $M$. chilensis and M. galloprovincialis, produced under controlled laboratory conditions [10]. M. galloprovincialis is well known to be a very drastic invasive species and is recognized as one of the 100 worst invasive species in the world [11,12]. Therefore, to understand the ecological and evolutionary processes that promote the invasion is of fundamental importance to elucidate the fecundity success and/or the presence of prezygotic barriers between crosses under laboratory controlled factorial designs.

\section{Methods}

Ripe blue mussels (35-64 mm shell length) were collected from the wild from Tumbes $\left(36^{\circ} 38^{\prime} \mathrm{S} ; 73^{\circ} 05^{\prime} 0\right)$; Yaldad ( $42^{\circ} 29^{\prime} \mathrm{S} ; 73^{\circ} 46$ '0) and Buque Quemado (52 ${ }^{\circ} 19 S$; $69^{\circ} 29^{\prime} 0$ ), corresponding to $M$. galloprovincialis, M. chilensis and M. edulis respectively [6]. Mussels were held in ambient running seawater until required for spawning. A factorial design was carried out to permit full reciprocal crosses. Fifty-five mussels from each species were exposed to air for about $1 \mathrm{~h}$, then placed in filtered seawater at ambient temperature, one mussel per beaker, for induction of spawning using thermal shock. Eggs and sperm were held for about $45 \mathrm{~m}$ at $18^{\circ} \mathrm{C}$ before use, to allow as many mussels as possible to spawn, thereby helping to synchronize the egg stage [13]. Eggs from each female were rinsed with filtered $(1 \mathrm{~mm})$ UV-irradiated seawater (FSW) and then resuspended in $2000 \mathrm{~mL}$ FSW at $18^{\circ} \mathrm{C}$ for fertilization. The spermegg ratio used for fertilization was approximately 100:1 in all trials. Eggs from each cross and each pure line were rinsed after $10 \mathrm{~m}$ to remove excess sperm and resuspended in two $3 \mathrm{~L}$ glass flasks (replicates) containing $2000 \mathrm{~mL}$ at a density 90-120 eggs mL [6].

The larval cultures were then maintained at $17^{\circ} \mathrm{C}$ and after 30 and 60 minutes, three samples of $15 \mathrm{~mL}$ were taken from each culture and fixed with $95 \%$ ethanol. The fixed sample was later examined in order to determine the percentage of eggs which had developed into a embryo. Three samples from each replicate flask were used to count the numbers of embryos larvae within one field of view (100 magnifcation). Evaluations of fecundity (three for each cross) were carried out using a Petroff-Hausser counting chamber. The spawned mussels were typed to confirm the especies indentification, using two PCR-based markers: Me15/16 [14] and COIXba [15]. The fecundity percentage in each cross, were analyzed using first the Cochran's $Q$ test for heterogeneity and then general linear models were applied.

\section{Results}

Fertilization occurred in all crosses and fecundation (cleavage) was observed within 25 to $60 \mathrm{~m}$ following mixing of eggs and sperm. Between 72 and $100 \%$ of fecundation at $30 \mathrm{~m}$ and $90 \%$ to $100 \%$ at $60 \mathrm{~m}$ were detected. Nested ANOVAs at $30 \mathrm{~m}$ and $60 \mathrm{~m}$ showed significant differences $(\mathrm{P}<0.05)$ among all crosses in the percentage of fecundity, however not significant differences between replicates were found. Similar statistical analysis showed no significant differences $(\mathrm{P}>0.05)$ between pure crosses (same species) and hybrids crosses (between species) with regard to the percentage of eggs developed into embryos (Table 1). A few abnormal larvae (less than $1 \%$ ) were detected by direct observation in the hybrid crosses, but the proportion of normal embryos during the early stages of growth showed no significant differences between pure and hybrid crosses.

Table 1: Results of Nested ANOVA for fecundity among Mytilus laboratory crosses.

\begin{tabular}{|c|c|c|c|c|}
\hline Factor & Source & df & SS & F-ratio \\
\hline \multirow[t]{2}{*}{ Fecundity } & Cross Replicate [cross] & 8 & 3714.66 & $90.848^{*}$ \\
\hline & Replicate [cross] & 9 & 5.11 & $0.704 \mathrm{NS}$ \\
\hline \multicolumn{5}{|c|}{ All crosses at 60 minutes alter fertilization: } \\
\hline Factor & Source & df & SS & F-ratio \\
\hline \multirow[t]{2}{*}{ Fecundity } & Cross & 8 & 397.92 & $10.331^{*}$ \\
\hline & Replicate [cross] & 9 & 43.33 & $0.747 \mathrm{NS}$ \\
\hline \multicolumn{5}{|c|}{ Between pure and hybrids crosses: } \\
\hline Factor & Source & df & SS & F-ratio \\
\hline \multirow[t]{5}{*}{ Fecundity } & Cross & 2 & 62.29 & $1.34 \mathrm{NS}$ \\
\hline & 30 vs $60 \mathrm{~m}$ & 1 & 342.51 & $7.39 \mathrm{NS}$ \\
\hline & Replicate [cross] & 5 & 8.23 & $0.18 \mathrm{NS}$ \\
\hline & Cross $\mathrm{x}$ minutes & 1 & 18.96 & $0.41 \mathrm{NS}$ \\
\hline & Error & 99 & 46,33 & \\
\hline
\end{tabular}

\section{Discussion}

The results of this study provide evidence that there are no differences in the percentage of fertilized eggs between pure line crosses and hybrid crosses between the three blue mussels belogning to the Mytilus genus found in coastal Waters of southern Chile. These results suggest that there is little or no evidence of prezygotic barriers to fertilization between these species. Therefore, there is a great posibility that the two exotic mussels present in the chilean coasts may interbreed with the native chilean mussel, causing a tremendous damage to the aquaculture industry in Chile. According to [16] there should be a prezygotic barrier between $M$. chilensis and M. galloprovincialis because a difference in the sperm morphology of the latter mussel. However, this study showed that the interbreeding between these two blue mussels is completely possible in both reciprocal crosses. Further investigations should be done, including larval abnormalities and juvenile mortality 
caused by incompatibilities between mitochondrial and nuclear genomes, that may be causing a higher frequency of abnormalities and lower survival among F1 hybrid larvae [17].

\section{Acknowledgments}

Funded by FONDECYT 1170194.

\section{References}

1. FAO (2018) Fisheries and Aquaculture software. FishStat Plus Rome.

2. Kotta J, Futter M, Kaasik A, Liversage K, Rätsep M, et al. (2020) Cleaning up Seas using blue growth initiatives: Mussel farming for eutrophication control in the Baltic Sea. Science of the Total Environment 709: 136-144.

3. Sernapesca (2020) Anuario Estadístico de Pesca.

4. Tarifeño E, Galleguillos R, Llanos Rivera A, Arriagada D, Ferrada S, et al. (2012) Erroneous identification of the mussel, Mytilus galloprovincialis (Lamarck 1819) as the specie, Mytilus chilensis (Hupé 1854) in the Bay of Concepción, Chile. Gayana 76: 167-172.

5. Astorga PA, Cárdenas L, Pérez M, Toro JE, Martínez V, etal. (2020) Complex spatial connectivity of mussels $\mathrm{M}$. chilensis along the Southeastern Pacific Coast and its importance for Resource Management. J Shellfish Res 39: 1-10.

6. Oyarzún PA, Toro JE, Cañete JI, Gardner JPA (2016) Bioinvasion threatens the genetic integrity of native diversity and a natural hybrid zone: smooth-shelled blue mussels (Mytilus spp.) in the Strait of Magellan. Biol J Linn Soc 117(3): 574-585.

7. Santaclara FJ, Espiñeira M, Cabado AG, Aldasoro A, González Lavín N, et al. (2006) Development of a method for the genetic identification of mussel species belonging to Mytilus, Perna, Aulacomya, and other genera. J Agric Food Chem 54(22): 8461-8470.

8. Díaz Puente B, Pita A, Uribe J, Cuéllar Pinzón J, Guiñez R, et al. (2020) A biogeography-based management for Mytilus chilensis: The genetic

\section{ISSN: 2574-1241}

DOI: $10.26717 /$ BJSTR.2021.34.005505

Jorge E Toro. Biomed J Sci \& Tech Res

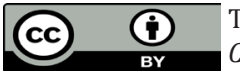

This work is licensed under Creative Commons Attribution 4.0 License

Submission Link: https://biomedres.us/submit-manuscript.php hodgepodge of Los Lagos versus the pristine hybrid zone of the Magellanic ecotone. Aquat Conserv 30(3): 412-425.

9. Comesaña AS, Toro JE, Innes DJ, Thompson RJ (1998) A molecular approach to the ecology of a mussel (Mytilus edulis- M. trossulus) hybrid zone on the east coast of Newfoundland, Canada. Mar Biol 133: 213-221.

10. Valenzuela A, Astorga MP, Oyarzún PA, Toro JE (2016) Caracterización genética de híbridos entre las especies Mytilus edulis platensis y $\mathrm{M}$. galloprovincialis en la costa Chilena. Lat Am J Aquat Res 44: 171-176.

11. McQuaid CD, Phillips TE (2000) Limited wind-driven dispersal of intertidal mussel larvae: in situ evidence from the plankton and the spread of the invasive species Mytilus galloprovincialis in South Africa. Mar Ecol Prog Ser 201: 211-220.

12. GISD (2020) Global Invasive species Database.

13. Toro JE, Thompson RJ, Innes DJ (2006) Fertilization success and early survival in pure and hybrid larvae of Mytilus edulis (Linnaeus, 1758) and M. trossulus (Gould, 1850) from laboratory crosses. Aquac Res 37(16): 1703-1708.

14. Inoue K, Waite JH, Matsuoka M, Harayama S (1995) Interspecific variations in adhesive protein sequences of Mytilus edulis, $M$. galloprovincialis, and M. trossulus. Biol Bull 189(3): 370-375.

15. Fernadez Tajes J, Longa A, García Gil J, Chiu YW, Huang YS, et al. (2011) Alternative PCR-RFLP methods for mussel Mytilus species identification. Eur Food Res Technol 223: 791-796.

16. Oyarzún PA, Toro JE, Garrido O, Briones C, Guiñez R (2014) Differences in sperm ultrastructure between Mytilus chilensis and Mytilus galloprovincialis (Bivalvia, Mytilidae): could be used as a taxonomic trait? Lat Am J Aquat 42: 172-179.

17. Rawson PD, Joiner KL, Meetze K, Hilbish TJ (1996) Evidence for intragenic recombination within a novel genetic marker that distinguishes mussels in the Mytilus edulis species complex. Heredity 77: 599-607.

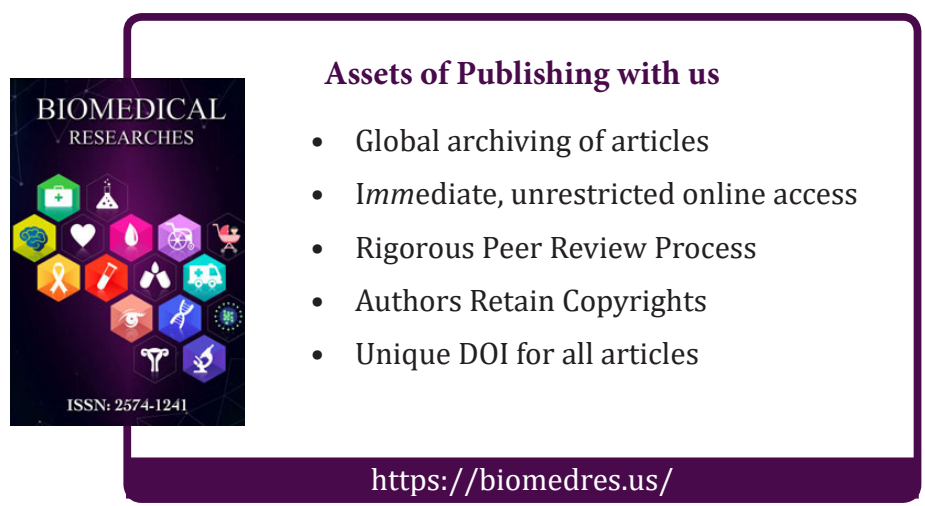

